\title{
Prevalência da Síndrome de Disfunsão em Jovens de 14 a 20 anos de idade. Utilização do índice Anamnésico de Helkimo.
}

\author{
Nunes, Rejane. C.D.* \\ Martins, Maria Cristina. C.D.** \\ Martins, Eleutério Araújo. Prof. Titular.***
}

\section{SUMÁRIO}

O presente trabalho inclui uma revisão da bibliografia pertinente à síndrome de dor e disfunção (SDD) dos músculos e da ATM no que se refere a estudos epidemiológicos. Foram avaliadas informações anamnésicas de sintomatologia, obtidas por questionário, bem como casos de ausência da mesma, em 200 estudantes situados na faixa etária de 14 a 20 anos, no sul do Brasil. Vinte e oito por cento $(28 \%)$ não relataram sintomatologia $\left(A_{i} O\right)$. Trinta e quatro por cento $(34 \%)$ relataram sintomas leves de disfunção $\left(A_{j} l\right)$. Trinta e oito por cento $(38 \%)$ relataram sintomatologia grave de disfunção $\left(A_{j} \mid l\right)$. Foi registrada uma prevalência de setenta e dois por cento $(72 \%)$ de pacientes relatando alguma sintomatologia de disfunção $\left(A_{i} \mid+A_{j} I I\right)$.

\section{INTRODUÇÃO}

A epidemiologia tem contribuido para o conhecimento, prevenção e tratamento de muitas doenças do século 20. A prevenção da cárie através do flúor e o relacionamento do fumo com câncer de pulmão e doenças coronárias, surgiram de estudos epidemiológicos.

No caso de disfunção mandibular, recentes estudos epidemiológicos sugerem que até $3 / 4$ da população podem estar, em algum grau, afetados por essa síndrome (1).

Muitos fatos etiológicos pesquisados em investigações prévias incluindo sexo, raça, $\theta$ grupos seletos $(2,3,4,5,6,7,8,9,1011,12,13$, $14,15,16)$, continuam sendo avaliados, embora de concreto, nenhum fator etiológico predominante tenha emergido desses estudos (17).
A Sindrome de Dor e Disfunção da ATM e músculos, em crianças e adultos jovens tem sido relatada $e$ avaliada exaustivamente na literatura nesta última década $(18,19.20$, $21,22,23,24,25,26,27,28,29,30$, $31,32,33,34,35,36,37,38,39,40$, $41,42,43,44,45,46)$.

A constatação de bruxismo em adultos $(47,48,49,50)$ e mais recentemente em crianças $(23,24,25,26$, $27,28,32)$, vem sendo relatada na literatura.

Eventuais implicações otorrinolaringológicas $(51,52,53,54,55)$, tem recebido atenção conjunta de médicos e dentistas.

$O$ crescente interesse pela SDD dos músculos e ATM, na última década, determinou a multiplicação de clínicas de tratamento de dor facial em conceituados centros médicos e odontológicos $(56,57,58,59,60,61$,
$62,63,64,65,66,67,68,69,70,71$, $72,73,74)$.

\section{MATERIAL E MÉTODO}

A população investigada foi composta de jovens, com idade variando entre 14-20 anos, de ambos os sexos, todos alunos de uma escola gratuita de propriedade do Governo Estadual do RGS. Embora localizada na grande capital é uma escola técnico-agrícola, procurada em grande parte por filhos de plantadores e criadores.

A região Sul do Brasil, é bastan-

\footnotetext{
*Interna. Disciplina de Oclusão

* *Interna. Disciplina de Oclusão

***Regente. Disciplina de Oclusão

Faculdade de Odontologla. Universidade

Federal R.G. do Sul
} 
te diferenciada climaticamente, por apresentar temperaturas extremamente baixas no inverno e, etnicamente por apresentar amplas zonas de imigração alemã e italiana. É uma região voltada basicamente para a agricultura e pecuária.

Para recolher as informações constantes nesse trabalho, foi utilizado o Índice Anamnésico de Helkimo, na forma de um questionário distribuído aos alunos, preenchido pelos mesmos, e avaliado estatisticamente. Os estudos mais recentes que utilizam o IDH, proporcionam os dados existentes mais comparáveis sobre epidemiologia da disfunção do sistema mastigador $(75,76,77,78$, 79). A medida que aumentam as informações ressalta a necessidade de um tipo de padronização para que as mesmas possam ser comparadas e que se possa estabelecer um quadro mais amplo abrangendo regiões geográficas diferentes bem como outras variáveis em que se incluam faixas etárias variadas (48).

\section{RESULTADOS}

De um total de 200 estudantes analisados anamnesicamente:

1. Cinqüenta e seis (56) estudantes não apresentaram nenhum sintoma, $-A i O=28 \%$.

2. Sessenta $\theta$ oito (68) estudantes relataram sintomas leves, - Ai I $=34 \%$. (fig. 1 ).

2.1. sons articulares: $47 \%$

2.2. fadiga dos músculos da face: $46 \%$

2.3. sensação de edema nos músculos faciais e ATM: $13 \%$

3. Setenta e seis estudantes (76), relataram sintomatologia considerada grave, $-\mathrm{Ai} I \mathrm{I})=38 \%$, assim distribuída, (fig.2) e (fig.3).

3.1. grande dificuldade de abrir a boca: $6 \%$

3.2. trancamento e luxações: $5 \%$

3.3. dor muscular aos movimentos: $25 \%$

3.4. dor articular: $20 \%$

O resultado global da investigação pode ser visto na fig. 4:

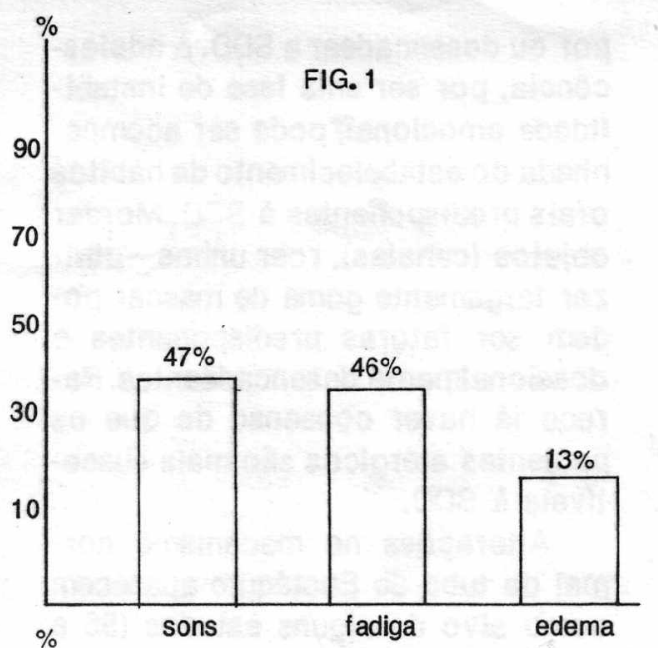

FIG. 2
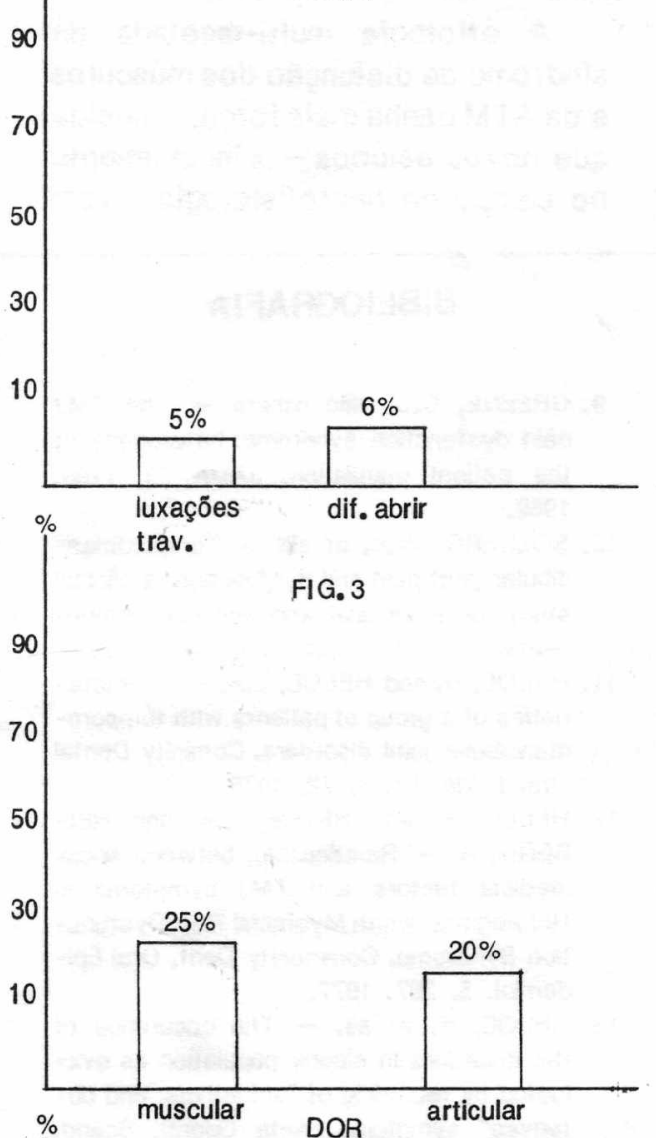

FIG. 4

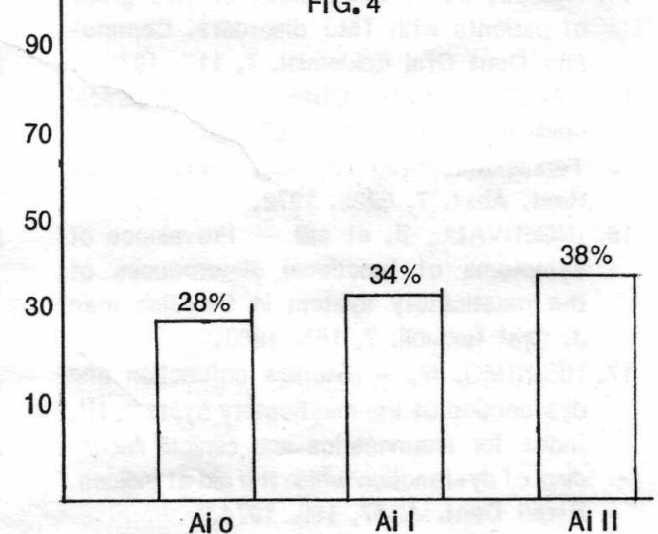

Ai O $=28 \%$

Ai I $=34 \%$

Aill $=38 \%$

\section{AVALIAÇÃO DOS RESULTADOS}

Os resultados obtidos, se somados $\mathrm{Ai}$ I + Ai II no trabalho $(72 \%)$, coincidem com aqueles relatados por Nilner e Lassing (44), que encontraram $72 \%$, e são semelhantes aos dados obtidos por Ericksson et allii (43), $60 \%$, Gazit et allii (46), $67 \%$, e Niliner, M., (45), $77 \%$. Os sons articulares, foram os sintomas mais relatados $(47 \%)$, junto com fadiga muscular $(47 \%)$. Os dados obtidos se situam próximos aos de Gazit (46), que encontrou entre 16-18 anos, $44,3 \%$, diferindo de Nilner (45), que encontrou $17 \%$ nas entrevistas e $14 \%$ no exame clínico, e Nilner e Lassing (44), $7-14$ anos $13 \%$ nas entrevistas e $8 \%$ ao exame clínico, indicando porém, que em ambos estudos houve uma tendência ao aumento de sintomatologia com aumento da idade.

Dor muscular $25 \%$ e dor articular $20 \%$, aparecem com percentagem próxima.

Se nos parece elevada a percentagem de $13 \%$ relatando sensação de edema (aumento de volume dos músculos faciais e ou ATM.

Grande dificuldade de abrir a boca, $6 \%$, e luxações e trancamentos da mandíbula, $5 \%$, foram os sintomas menos referidos, o que confirma observações de Helkimo (81).

As observações até agora feitas em nosso meio $(80,48)$ se assemeIham a dados coletados por investigadores prévios no que se refere a prevalência da SDD dos músculos e da ATM.

Parece ser recomendável uma investigação mais abrangente, incluindo crianças de faixa etária de 3 a 13 anos e pacientes prévios a tratamento. or todôntico recomendado. Também parece recomendável uma avaliação clínica (Di), de pacientes com problemas na área de otorrinolaringologia, principalmente aqueles com problemas alérgicos. 


\section{DISCUSSÃO}

Nenhuma das escolas de oclusão que defenderam por algumas décadas diversas teorias e técnicas de reconstruções oclusais amplas, apresentou dados inequívocos com respeito à uma seleção sistematizada de casos, com sintomatologia estabelecida, nem relatórios de acompanhamento, a médio e longo prazo, dos resultados obtidos com os tratamentos preconizados quanto à remissão de sintomatologia. Parece estar claro hoje, que muitos tipos de tratamentos impostos apresentam resultados satisfatórios, o que leva à conclusão que sendo eliminado um entre os muitos fatores etiológicos eventualmente presentes a sintomatologia pode regredir.

Várias causas parecem predis- por ou desencadear a SDD. A adolescência, por ser uma fase de instabilidade emocional, pode ser acompanhada do estabelecimento de hábitos orais predisponentes à SDD. Morder objetos (canetas), roer unhas - utilizar largamente goma de mascar podem ser fatores predisponentes e ocasionalmente desencadeantes. Parece já haver consenso de que os pacientes alérgicos são mais suscetiveis à SDD.

Alterações no mecanismo normal da tuba de Eustáquio aparecem como alvo de alguns estudos (56 a 59) que tentam 0 estabelecimento de uma relação "otodental".

A etiologia multi-facetada da síndrome de disfunção dos músculos e da ATM ganha mais força, a medida que novos estudos - principalmente no campo da neurofisiologia - vem sendo dados ao conhecimento da comunidade cientffica.

\section{CONCLUSÕES}

1.Os resultados obtidos confirmam aqueles relatados em diversos estudos epidemiológicos realizados na mesma faixa etária $(43,44,45,46)$ em grupos étnicos diversos, mostrando uma prevalência bastante alta da $A D D$;

2. A sintomatologia relatada é bastante diversificada;

3.Parece ser desejável a complementação de estudos anamnésicos por levantamentos através de exames clínicos rigorosos, para comparação.

\section{BIBLIOGRAFIA}

1. CHARLES S. GREENE and JOSEPH J. MARBACH - Epidemiologic studies of mandibular dysfunction: A critical review. J. Prost. Dent. 48, 184-189. 1982.

2. AGERBERG, C. and CARLSSON, G.E. Fundtional disorders of the masticatory system, I. Distribuition of symptoms, according to age and sex judged from investigation by questionnaire. Acta Odont. Scand. 30, 597, 6-13. 1972.

3. AGERBERG, G. and OSTERBERG, T. Maximal mandibular movements and symptoms of mandibular dysfunction in 70 years old men and women. Swed. Dent. J, 67, 1-17. 1974.

4. AGERBERG, G. and CARLSSON, G.E. Symptoms of functional disturbance of the masticatory system. A comparison of frequencies in a population sample and a group of patients. Acta Odont. Scand. 33, 183. 1975.

5. LUNDEEN, T.F. et allii - Discriminative ability of the TMJ scale: age gender differences. The J. of Prosth. Dent 56 1. 1986.

6. AGERBERG, G. - Maximal mandibular movements in young men and women. Sven. Tandlak. Tidsk 67, 81. 1974.

6. AGERBERG, G. - Maximal mandibular movements in young men and women. Sven. Tandlak. Tidsk 67, 81. 1974.

7. CARL, E. RIEDER, et allii - The prevalence of mandibular dysfunction, part I: sex and age distribuition of related signs and symptoms. J. of Prosth. Dent 50 (1) 81. 1983.

8. WOODROW, J. at alli - Pain tolerance: difference according to age sex and race. In Weinsenberg, $M_{\text {. editor Pain Clinical }}$ Perspectives, St Louis 1975. The C.V. Mosby Co. pp.133. 1975.
9. GREENE, C.S. and others - The TMJ pain dysfunction syndrome: heterogeity of the patient population. JADA 79, 1168. 1969.

10. SOLBERG, W.K. et allii - Temporomandibular joint pain and dysfunction: a clinical study of emocional and occlusal components. J. Prosth. Dent. 28, 412. 1972.

11. HELOE, B. and HELOE, L.A. - Characteristics of a group of patients with temporomandibular joint disorders. Cominity Dental Oral Epidemiol. 3, 72. 1975.

12. HELOE, B. and HELOE, L.A. and HEIBERG, A. - Relationship, between social medical factors and TMJ symptoms in Horwegians whith Myofacial Pain Dysfunction Syndrome. Community Dent. Oral Epidemiol. 5, 207. 1977.

13. HELOE, B. et all. - The occurence of the disorders in elderly population as evalueted by recording of "subjetives, and $o b$ jetives" symptoms. Acta Odontl. Scand. $36,3.1978$.

14. HELOE, B. - Comparison of two group of patients with TMJ disorders. Community Dent Oral Epidemiol. 7, 117. 1979.

15. HANSSON, T. and OBERG, T. - A clinical epidemiological study of 67 years in Dalby. Tandlakatidningen $63,650.1971$. or Oral Rest. Abst. 7, 5228. 1972.

16. INGERVALL, B, et allii - Prevalence of symptoms of functional disturbances of the masticatory system in Swedish men J. Oral Rehabil. 7, 185. 1980.

17. HELKIMO, M. - Studies onfunction and dysfunction of the masticatory system, III. Index for anamnestics and clinical recording of dy sfunction whith the aid of indices. Swed Dent. J. 67, 165. 1974.

18. HELOE, B. et all. - Frequency and distri- buition of Myofacial Pain-Syndrome in a population of 25 years old. Community Dent. Oral Epidemiol. 7, 357. 1979.

19. INGERVALL, B. - Tooth contacts on trh functional and non functional side in children and young adults. Archieves of Oral Byology, 17, 191. 1972

20. INGERVALL, B. - Prevalence of dental and occlusal anomalies in Swedish conscripts. Acta Odont. Scand. 32, 83. 1974.

21. INGERVALL, B. - Range of movements of mandible in children. Scand. J. Dent Res. 78, 311. 1970.

22. EGERMARK, ERICKSSON, I. - Prevalence of headache in Swedish school children. A questionnaire survey. Acta Pediat. Scand. 71, 135. 1982.

23. EGERMARK, ERICKSSON, I. - Maloclusion an ame functional recordings of the masticatory system in Swedish school children. Swed. Dent J. 5, 125. 1983.

24. EGERMARK-ERIKSSON, I. et allii - The dependence of mandibular dysfunction in children on functional and morphologic maIoclusion. Am. J. Orthod. 88 (3), 187. 1983.

25. LINDQVIST, B. - Bruxism in children. Odont Revy 22, 413. 1971.

25. LINDQVIST, B. - Oclusal interference in children whith bruxism. Odont. Revy, 24, 141. 1973.

27. LINDQVIST, B. et all - Bite force in children whith bruxism Acta. Odont Scand. 31, 255. 1973.

28. INGERSLEV, $\mathrm{H}_{0}$ - Functional disturbance of the masticatory system in school children. J. Dent. Child 50 (6) 445-1983.

29. SCHNEIDER, P.E. - Oral habits. Considerations and management. Pediatr. Clin. North Am. 29 (3) 523. 1982.

30. MARKS, M.B. - Bruxism in allergic chil- 
dren. Am. J. Orthod 7, (1), 48. 1980.

31. WILLIAMSON, E. H. $_{0}$ - Temporomandibular dysfunction in pretreatment adolescent pacients. Am. J. Orthod. 72, 429. 1977.

32. $\mathrm{KUCH}, \mathrm{E}_{0} \mathrm{~V}$, etall - Bruxing and non bruxing children. A comparison of their personality traits. Ped. Dent. I (3) 182. 1979.

33. REIMAO, R. et all - Prevalence of nocturnal bruxism in chilhood. Rev. Hosp. Clin. Fac. Săo Paulo Med, 37, 228. 1982.

34. RUBINA AHMAD - Bruxism in children - The J. of Ped. 10-2, 105. 1986.

35. ZARB, G. and THOMPSON, G. - Mandibular (TMJ) dysfunction in young adults. Umpublished mnuscript.

36. UZHUMETSKENE, I. - The incidence of functional disorders in temporomandibular joint adults. Stomatogila (Mosk) 51, 43. 1972. or Oral Res. Abstr. 8, 5934. 1973.

37. GEERING-GA日NY, M. and RAKOSI, T. - Initial symptome von.e. Kiefergelenkstorungen bei Kinder in Alter von 8-14 Jahren Schweizerisch Monatsschrift für Zahnnheilkunde 81, 691. 1971.

38. LINDQVIST, B. - Bruxism in twins. Acta Odot. Scand. 32, 177. 1974.

39. INGERVALL, R. and HEDEGARD, B. Subjetive evaluation of functional disturbance of the masticatory systrm in young men. Community Dent. Oral Epid. 2.149. 1974.

40. MOHLIN, C. et allii - Frequency of symptoms of mandibular dysfunction young Swedihs men. J. Oral Reahbil. 3, 9. 1976. 41. GROSFELD, O. and CZARNEKA, B. Musculo articular disorders of stomathomatognatic system in school children examined according to clinical criteria. J. Oral Reahbil. 4, 193. 1977.

42. SOLBERG, WKe, et allii - Presvalence of mandibular dysfunction in young adults. JADA, 98, 25. 1979.

43. ERICKSSON et allii - Prevalence of mandibular dysfunction, and orofacial parafunction in 7-11-and 15 years old Swedish children. European J. of Orthodontics 3 , 163. 1981.

44. NILNER, M. and Lassing, S. - Prevalence of functional disturbances and diseases of the stomatic system in 7-14 years old. Swed. Dent. J. 5, 189. 1981.

45. NILNER, M. - Prevalence of functional disturbance and diseases of the stomagnathig system in 15-18 years old. Swed. D. J. 5, 189. 1981 .

46. E. GAXIT et allii - Prevalence of mandibular dysfunction, in 10-18 years old laraeli school children. J. of Oral Rehab. 307. 1982.

47. SIMŐES SANTOS, A. et allii - Sindrome de dor e disfunçăo do sistema estomatognático. Análise anamnésica de 110 casos. Rev. Gaúcha de Odnt. n: 6, vol. 34. 1986.

48. NUNES, $R_{0}$ et allii - Sindrome Temporomandibular de dor e disfunção - Epidemio- logia. No prelo da Rev. Gaúcha de Odont.

49. HOLM, A. K. - Oral Health in 4 years old Swedish children. Community D. Oral Epid. 3, 25. 1975.

50. HOLM, A.K. - Oral Health in 5 years old Swedish children. Community D. Oral Epidem. 3, 184. 1975.

51. HOLM, A.K. - Dental health in a group of Swedish 8 years old, followed sinse the age of 3. Community Oral Epid. 6, 71. 1978.

52. CLARKE, N.G. et all - Distribuition of nocturnal bruxism, patterns in men. J. Oral Reahbil. 11. (6) 529. 1984.

53. CLARKE, N.G. et all - Bruxing patterns in men during sleep. J. Oral Reahbil. 11 (2) 123.1984.

54. CLARKE, N.G. - Occlusion and myofacial pain dysfunction: is there a relationship? J. of Am. D. Assoc. 104, 443. 1982.

55. CLARKE, N.G. et allii - Bruxing patterns in men during. J. of Oral Reahbil. 11, 23. 1984.

56. ARLEN, H. - The otomandibular syndrome: A new concept. Ear, Nose, Throat J. 26, 30. 1977.

57. ARLEN, H. - Otolarynologic manifestation of craniomandibular disorders. Dent. Clin. of North Amer. 27, 523. 1983.

58. ROOD, S.B. et all - Morphology of tensor veli palatini, tensor tympani and dilator tubal muscles. Am. Otol. Rhin Laryng. 87, 202. 1978.

59. HOLBOROW, C. - Eustachian tubal function, changes in anatomy and function whith age and relationship of these changes to aural pathology. Arch Otolaryngol. 92, 624. 1970.

60. MAGNUSSON, T. et all - Comparisson between two groups of patients in respect to headache and mandibular disffunction. Swed. Dent. J. 2, 85. 1978.

61. KAYE, $L$ et allii - Statistical analises of urban population of 236 patients whith headache and neck pain, part I. Patient profile J. Period. 50, 55. 1977.

62. MAC NEILL - Craniofacial pain. The management dilemma. J. Calif. Dent. Assoc. pp.34, 49. 1984.

63. TAKADA, K. et allii - Clinical study of temporomandibular disturbances I. Statistical observations of patients whith temporomandibular arthrosis. J. Osaka. Univ. D. Sch. 11, 7. 1971.

64. ROSEMBARG, H.N. et all - TMJ radiografy whith enphasis on tomography. Dental Radiogr. Pfotogr. 55, 1. 1982.

65. KATZBERG, R.W. - Arthromography of the tewmporomandibular joint. Amer. J. Radiol. 134, 995. 1980.

66. HELMS, C.A. et all - Computed tomography of the meniscus of the temporomandibular joint. Preliminary abservations Amer. J. Radiol. 152, 459. 1984.

67. ROBERTS, D. et all - Three dimensional imaging and display of the temporomandibular joint. J. Oral Surg. 58, 461. 1984.

68. PHERO, J.C. - Pharmacotherapy for cronic facial pain. Dent. Clin. of North Am. vol. 28, 3. 1984.

69. HALL, La. - Physical therapy treatment results for 178 patients whith temporomandibular joint syndrome. The Am. J. of Otology 5, 3. 1984.

70. RIEDER, C. - Comparisson of the efficacy of the question naireoral history and clinical examination in detecting occlusal temporomandibular jint dysfunction sings and symptoms. J. Prosthet. Dent. 38, 433. 1977.

71. WEINGBERG, I. et all - Clinical report on the etiology and diagnosis of the TMJ dysfunctions pain syndrome. J. Prosthet. Dent 44, 642. 1980.

72. HANSSON, T. et all - A study of the occurrence of symptom of diseases of the TMJ, masticatory musculature and related strutures, J. Oral Reahbil. 2, 313. 1975.

73. GELB, H. et allii - The role of the dentist and the otolaryngologist in evaluating temporomandibular join syndrome. J. Prosth. Dent. 18, 497. 1967.

74. GELB, $H_{0}$ et all - A two year clinical dental evaluation, of 200 cases of cronic headache. The craniocervical mandibular syndrome. J. Am. Dent. Assoc. 91, 1230. 1975.

75. RAMFJORD and ASH - Oclusão. 1983.

76. HELKIMO, M. - Studies on function and dysfunctions of the masticatory system. Dissertation. Universityof Gotemborg Sweden. 1974.

77. HELKIMI, M. - Studies on function and dysfunction of the masticatory system I. an epidemiological investigation of symptoms of dysfunction in Lapps in the North of Finland. Acta Od. Scand. 32, 255. 1974.

78. HELKIMO, M. - Studies on function and dysfunction of the masticatiry system. Index for anamnestics and clinical and occlusal state. Swed. Dent. J. 67, 101. 1974.

79. HELKIMO, M. - Epidemiological surveys of dysfunctions of the masticatory system. In: Zarb, G.A. and Carlsson, G.E. Temporomandibular Joint, Function and dysfunction. Munksgaard, Copenhagen. p.175. 1979.

80. MAINIERI, E. et all - Controle epidemiológico da incidência de alterações da articulação temporomandibular e sistema estomatognático, em 300 pacientes. Rev. Gaúcha de Odont. 21 (2) 150. 1973.

81. HELKIMO, M. - Comunicação pessoal. 1985.

\section{OBSERVAÇÃO:}

TRABALHO REALIZADO COMO PARTE DO PLANO DE ATIVIDADES EM INTERNATO NA DISCIPLINA DE OCLUSÃO ODO218-1986 